Vladimir Dragojlović ${ }^{1}$

University Business Academy, Novi Sad,

Faculty of Applied Management,

Economics and Finance, Belgrade

Branko Mihailović

Institute for Agricultural Economics, Belgrade

Srđan Novaković ${ }^{3}$

University Business Academy, Novi Sad,

Faculty of Applied Management,

Economics and Finance, Belgrade
SCIENTIFIC REVIEW ARTICLE

doi:10.5937/ekonomika1804133D

Received: October, 09, 2018

Accepted: November, 05, 2018

\title{
MARKETING ACTIVITIES FOR THE PURPOSE OF MARKETING CULTURE DEVELOPMENT IN EDUCATION AND EDUCATIONAL INSTITUTIONS
}

\begin{abstract}
Education, as one of the most complex human activities, cannot work and develop in contemporary conditions without the implementation of current knowledge from other sciences and scientific disciplines. There is an undeniable contribution which can be provided to education by means of marketing and development of marketing orientation. In this process, a special responsibility belongs to school management which should methodically run its organization from school to marketing culture, thus achieving goals related to greater efficiency and quality of school. Such management would enable the school to react more efficiently to changes in the environment, to new services offer, successful market operations and to perform activities in accordance with the requirements and expectations of internal and external users of services.
\end{abstract}

Key words: education, management, marketing, culture, organization

Jel Classification: I29, M31

\section{МАРКЕТИНГ АКТИВНОСТИ У ФУНКЦИЈИ РАЗВОЈА МАРКЕТИНШКЕ КУЛТУРЕ У ОБРАЗОВНО-ВАСПИТНИМ ИНСТИТУЦИЈАМА}

\begin{abstract}
Апстракт
Образовање, као једна од најсложенијих људских делатности, у савременим условима не може функционисати и развијати се без имплементаџије актуелних сазнања из других наука и научних дисциплина. Неспоран је допринос који образовағу може пружити маркетинг и развијање маркетиншке оријентације. У овом процесу посебну одговорност има менаимент школе
\end{abstract}

\footnotetext{
${ }^{1}$ dragojlov@yahoo.com

2.brankomih@neobee.net

${ }^{3}$ srdjan.novakovic@mef.edu.rs
} 
који своју организачију треба плански да води од школске ка маркетиншкој култури чиме би се остварили ичиљеви везани за већу ефикасност и квалитет школе. Такав менаимент би омогућио брже реаговање школе на промене у окружењу, на понуду нових услуга, успешно тржишно пословање и обављање делатности у складу са потребама и очекивағима интерних и екстерних корисника услуга.

Кључне речи: образовање, менацмент, маркетинг, култура, организаџија

\section{Introduction}

The public education system has long been facing great challenges and changes, various reform attempts, tendencies and directions. We are witnessing constant reform measures in the educational system that range from original individual solutions to the imposed and dominant solutions in line with the educational policies of the European Union.

Public sector schools posess every characteristic of non-profit and service providing organizations. As such, they have suddenly found themselves in an environment characterized by the existence of an educational market and competitive business conditions. This entire ambiance is in particular determined by large demographic changes, which is clearly reflecting the reduction of the already limited education market. Also, the demands and expectations of internal service users are increasing. Both they and the educational authorities insist on the highest quality of educational services. All of the above mentioned is happening in a situation where financial resources for this purpose are increasingly limited and insufficient.

Characteristics and functions of marketing of the non-profit and service providing sector are also applicable to educational activity, of course with respect to certain specificities. Earlier schools have used some sort of marketing as well, often unconscious of the fact that the activities they were conducting were actually marketing activities. Such attempts were mostly unplanned and random. For many of the problems that today's Elementary Schools are facing, marketing has already provided complete solutions, therefore any speculation and search for solutions beyond marketing would mean "knocking at the open door". A school which is marketing-oriented and has a high level of development of marketing culture has all the prerequisites for domination in the education market. It will position itself in the local community as a prestigious school that successfully operates and has satisfied internal and external users of its services.

One of the main tasks of school management should be the specific marketing activities which would grow the existing school organizational culture into a marketing culture. It would enable teachers and professors to be more engaged in meeting the requirements, wishes and expectations of students, parents and the local community, while at the same time enabling them to meet their own needs as well as requirements of the school employed at.

Apart from the need to modify the current organizational culture in this direction, certain knowledge in the area of marketing is also required. Throughout this reform process, the importance and role of a school manager as a person who is most responsible for top quality and successful business of schools is vital. In that sense, dealing with marketing activities should become another one of his daily management activities. Of course, he cannot do this by himself or as a part of a certain professional team, but he must try to develop awareness among all employees about the need to accept the marketing orientation of his school and the necessity of developing a marketing culture. 


\section{Changes in the school environment}

Current educational practice requires the necessity of applying a marketing concept in educational institutions as a guarantee of their successful functioning in the education market.

Schools from the public sector completely share the fate of the society and the state in which they perform their activities and which had founded them. The numerous social, economic, political and globalization problems reflect the work and functioning of the Elementary School, whereby constant exposure to the public judgment only contributes to the increased critical attitude towards it, whether dealing with the concerned public or external and internal users of services.

The processes of democratization and transition that had occurred in our country in recent decades have opened the path for many social changes. Of course, these changes also affected the domain of education as one of the most complex and most dynamic human activities. Speaking about the process of transition P. Rado (2002, p. 13) discusses its three components:

- transition from a totalitarian system to a free, democratic system

- $\quad$ overcoming deep structural economic crises by moving from planned, stateowned economies to free-market economies

- modernization, adaptation to dramatic global changes

Education and education policy had to respond to the demands of all three components and the reform was mainly performed in terms of moving, striving for a type of role model, pattern. Mostly European models and European standards are becoming the main goals of the education policy, rather as a result of the proclaimed preparations for joining the European Union. This is also related to the emergence of the private sector in education and its functioning on typical market principles, which was first felt in the field of high and pre-school education and slightly in the field of primary and secondary education. Such a possibility was created because the transition in education enabled the transition from a conductive system to a demand-based system (P. Rado, 2002, p. 23), which among other things implies that students are the central point of educational policy, that the focus is on learning outcomes, improving the quality of the educational process and cost-effectiveness, that the system is decentralized and liberalized, that the number of interested parties involved in education has increased etc.

Also, along with the process of democratization of society, the process of decentralization exists as immanent. In the field of education, it means that certain powers are conferred to schools, providing them greater autonomy primarily in terms of independent decision-making about the content and offer of their service programs. This enables schools to more systematically analyze the needs of their immediate surroundings in new market functioning conditions and to respond more adequately to the identified needs.

Slovenian author Metod Resman discusses the organizational and political decentralization (2004, p. 14-15), where, under organizational decentralization, he considers a technical solution by which the central educational authority organizes its administrations throughout the entire territory of the state, and manages school system by means of such an administrative apparatus, while political decentralization implies the transfer of powers to local educational authorities provided that they are able to independently manage education in their territory and states that for this decentralization there are three key reasons:

- financial: more rational business using available funds,

- professional: greater participation of teachers, and therefore greater motivation for better work,

- ideological: adapting the program to the requirements of the school environment, respecting the culture of interpersonal relationships. 
Marzano R., Waters T., McNulty B. define and summarize their observations on the school environment using a sentence that the school is not an island (2005, p. 58), and that it functions in a complex context to which special attention is to be paid if one wants its performance to be of high efficiency. The school Principal is required to show willingness to be a school representative and exponent in front of the people in charge of the school, which means that he must be willing and able to communicate with individuals inside and outside school. In short, the authors $(2005$, p. 58) insist on expanding partnerships outside the school framework, i.e. justifying their position by the fact that "for raising a child participation of all of us matters", with the recommendation that the school has the obligation to follow all state and local laws and regulations, and that it is the duty of the director to be a school representative with the parents, within school management and the wider community.

Although good relations of educational institutions with the environment were always important, and today they represent the existential requirement for their survival (S.Staničić, 2011, p. 59), in practice, schools continue to act in different ways towards the environment. Some schools view themselves as a closed system with no external influences. In contrast, some schools consider themselves as a wide open institution, and see the opportunity in the environment to present their values and attract users.

From a number of factors from the external environment that directly or indirectly influence to the functioning of the school as an organization and consequently to the overall results of the educational process, the demographic factor is the most important factor that is in line with the subject matter of this paper. The basic characteristic of demographic factors in our society relates to the rapid decrease in the number of inhabitants as a result of an ever smaller number of newborns, i.e. the extremely negative population growth. This reflects the school as it remains with an ever-decreasing number of enrolled students, generally smaller number of total service users, which undermines the survival of many schools and many public sector education jobs.

It is interesting that these negative trends and changes in the environment related to the smaller number of pupils in schools are more dealt with by the media, often with their sensational texts, than by the professional public and by the creators of the state education policy.

Exact and reliable data on the decline in the number of pupils in schools is published by the Statistical Office of the Republic of Serbia.

Chart 1. Number of Pupils in Elementary Schools in Serbia by years

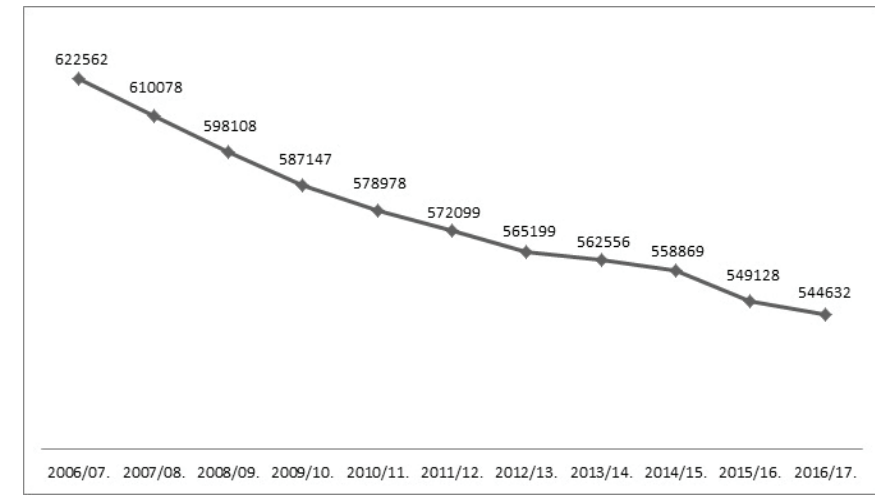

Source: www.rzs.stat.gov.rs 
From the reliable data published by the Statistical Office of the Republic of Serbia, a rapid decrease in the number of students in Serbian Elementary Schools can be noticed. In the 10-year period, this number is lower for almost 80,000 students. The decline in the number of students per year goes straight to a negative trend and the assumption is that such a trend will continue.

The direct consequence of these changes is the phenomenon of the so-called technological surpluses in the area of primary education, the emergence of more and more teachers with insufficient number of classes, anxiety before every new entry of first grade pupils, attempts of schools to use their resources and make the school more attractive to potential students promoting their activities and offering special and specialized programs, with the ultimate goal of ensuring the survival of the school.

In such an environment, realizing the seriousness of the problem, some schools and their managers are directing their organization towards a new idea - the marketing orientation, aware that in the education domain only those schools which are marketoriented and focused on meeting the needs of the target market will survive.

\section{Marketing culture and marketing planning at school}

The new problems faced by today's school have resulted in the need to develop more effective communication between the school and the beneficiaries of services, to build a good image and a positive climate and culture in the school, and to make the school itself as efficient organization as possible.

J. Pavičić (2001, p.103), adapting various definitions, defines the application of marketing i.e. the marketing orientation of a non-profit organization as: an organizational culture that shapes the behavior required for "creating superior value for users and for continuous superior performance". Based on the results of some empirical research he says that organizations that are systematically using marketing, i.e. are "marketingoriented" achieve better results in their performance compared to the target groups they address to than those who rarely or sporadically use or do not apply marketing at all.

One of the special forms of organizational culture is marketing culture. Marketing culture is reflected in the quality of work, the satisfaction of students, parents and teachers, in mutual relations, competitiveness, organization, internal communication and innovation (V.Logaj et al., 2006, p.6). The authors believe that marketing culture has particular practical value, which can play an important role in the prevention of some current problems in the school, such as various forms of violence, lack of instruction, lack of motivation and dropout of students, while at the same time it can increase the identification of teachers and pupils with school and strengthen the position of the school in the local community.

In education, marketing is an active and creative process. Due to its recent application it can be seen as a reform process and innovation. It involves engagement in the implementation of specific tasks, it includes a range of different activities, which requires quality strategic marketing planning in the school. Current school practice shows signs of implementing marketing activities, but the issue of their adequate planning is posed, thus imposing the necessity of urgently required training of teaching staff in the domain of marketing. Currently, the expectations of teaching staff are that the school Principal, as the most responsible for its successful functioning, should undertake an initiative in the field of planning and realization of marketing activities. In this area he can establish a team of marketing associates and carry out the redistribution of duties and responsibilities among employees, but it is most important to influence the awareness 
of all of his employees regarding the importance of applying marketing activities and marking orientation of school.

As much as schools plan well and realize their marketing activities, it will never be possible for all schools in the local community to be fully satisfied with the results achieved, especially when it comes to the number of students enrolled in school. This is the problem of a restricted market, as the case is with educational market, where the new number of pupils of the first grade will never be enough to satisfy all the schools. Some schools will be more successful, but at the expense of other schools. If any school makes a success in this activity, it automatically means that some other school has come to a problem situation. Herein a clear conclusion can be made that success will only be achieved by those schools that are more successful in the field of planning and realization of marketing activities.

In our country, each school is obliged to make place for a separate section to marketing in school in its Annual Work Plan which is the operational document of each school, in accordance with the envisaged structure of the said document. Although untrained for dealing with marketing matters and marketing issues, schools act in accordance with the instructions they receive from competent educational authorities. It is suggested that the section "The Plan for the Implementation of School Marketing Programs" should contain information on the planned activities in the field of internal marketing (information and presentation of school activities by means of site, announcements, school list, bulletins, yearbooks, bulletin boards, book notifications) marketing (information and presentation of school activities in the media, as well as cooperation with economic organizations, other schools and institutions). It is clear that schools adhere to such suggestions, which, unfortunately, only deepen the already existing gap in the correct understanding of the concepts of marketing, marketing communication and promotion. Hence we have come to complete equalizing these terms concerning their meaning. Therefore, in the school practice, in the Annual Work Plans section, specifically promotion and communication are stated, which is far from one of the simplest determinations of marketing, according to which the marketing process of communication between the organization and the target groups deals with satisfying the existing and anticipating the awakening needs of the target group and organizes market research in order to provide information on the needs and requirements of the target groups.

Planning, as a basic requirement for the successful realization of some activity, is an important segment of marketing activities in the school. In an attempt to obtain a clearer picture of the situation in our schools, by the random sample method web sites of over 50 elementary schools in Serbia were analyzed, namely their Annual Work Plans and planned marketing activities. The analysis shows that in most cases this topic is mainly about promotional activities and communication. Among the schools themselves, there are large differences in the way in which marketing is perceived, and some characteristic observations are distinguished:

- All schools distinguish the internal and external marketing

- Under internal marketing, they consider school boards, school site, fb site, and under external marketing they consider activities of informing the general public about everything that happens in school through local media, publishing student literary and artwork in children's magazines

- Some schools have formed teams for school marketing, defined team members and coordinators, detailed action plan, method of realization, place, time and executors

- In most schools, among the planned pre-marketing activities events on the reception of pupils of first grade are predominate, as well as children's 
workshops, exhibitions of fine arts, handicrafts and artistic works, sports day, editing and updating of the site of the school and fb site, production of suitable materials representing school - brochures, badges, $t$-shirts, school supplies with school logos, issuing school leaflets, marking significant dates, participation in municipal, regional and republican festivals and competitions

- One school notes that school activity has to be presented with as much marketing as possible, that school marketing is very poorly developed mainly due to lack of funds, but also inadequately trained marketing staff and sees the solution in intensifying internal marketing by editing the site and by upgrading the information system of the school with automatic data processing

- The other school sees the opportunity in marketing for further development and improvement of the reputation and image of the school and its promotion not only in the local community, but also in the wider region; plans to pay special attention to cooperation with parents with an emphasis on improving the teacher-pupil-parent relationship and establishing a high quality cooperation with the social environment

- In external marketing, the school sees the chance to properly present the public everything that has been well done in school, and to center the interest of the local community and others to all problems related, for example, to the material position of the school, working conditions, etc.

- Some schools have fully delegated the planning of marketing activities and the responsibility for the implementation of the same to the person they designated as "school PR"

- Only one school has planned the activity of presenting itself in preschool institutions in order to attract a greater number of future users of their services, i.e. first grade pupils

- As promotional instruments schools mainly use written material and promotional events.

Such diversity in practical marketing approaches is at the same time a great possibility to create good and original ideas and a good opportunity for elementary schools, since some of them see a chance to solve some of their current problems and improve their work using marketing. Such a wealth of diverse approaches and ideas should only be accompanied by a unique layout of the marketing plan for each elementary school.

At the same time, by insufficiently broad and correct understanding of marketing, schools do nothing to implement the identification and attraction of future users of their services, as well as potential sponsors or donors. The essence in school practice is that the entire marketing activity is reduced to informing users of the various activities that the school implements, especially emphasizing successes and awards, which is reduced to the segment of public relations activities and to improving the image of the school in the awareness of service users and the wider local community. However, according to Grubor A. and Đokić N. (2014, p. 32) promotion has an unquestionable importance in image building, but "for its full realization, interaction is necessary, and even the synergistic effect of promotion with other marketing mix instruments."

The analyzed status identifies, in a sense, the concept of marketing as a link between school and service users. To a certain extent, but not sufficient, this approach has satisfied some of the needs of both schools and users. However, these arguments prove that this is insufficient and does not reflect the true sense of marketing and marketing 
activities. Also, in the analysis one does not find any indication that any school in the marketing activities has planned or realized any activity related to monitoring or research of changes in the environment, and therefore there are no plans or strategies to adequately address these changes.

One of the few authors from the region who studied marketing culture A. Bajric (2008, p. 52), in his analyzes concludes that marketing culture is at a rather low level and that research in this field is extremely scarce. In practice, he concludes that some schools use certain marketing tools in marketing communication with the environment and target groups while some schools do it without knowing that it in fact is marketing communication. The intensity of this communication is particularly increasing between high schools and finishing elementary school pupils and their parents, with the aim of enrolling these students into their school. He notes that some schools are particularly skillful in marketing communication, using the achieved results in learning at municipal, republic and international competitions. Schools that do not enroll a sufficient number of students undertake some marketing activities mainly by offering new programs but without sufficient research and analysis of the needs of the users of their services. Marketing communication is mainly directed to advertising of some presentations, to distributing of written materials, etc., but in general, schools still leave the impression of sleepiness and do not respond adequately to changes in the wide and close environment.

\section{Responsibility of school management in planning marketing activities}

Different documents, whether legislative or research ones, directly or indirectly foresee the head of the educational institution to deal with the issues of marketing in education, meaning that marketing activities are his own obligation within the stated field of work and the stated responsibility.

This way, dealing with marketing activities becomes another in a series of managerial activities of school Principals. And in this area he must plan, organize, manage, lead and evaluate. Through marketing activities, the Principal will successfully communicate with numerous users and in particular will easily identify and meet the needs and wishes of the employees. Precisely in all of his human resources he needs to look for associates and partners in the planning and realization of marketing activities in the school, so that the entire school can get a recognizable marketing orientation. It is unacceptable for all the care and marketing obligations to be reduced to the Principal or group of his closest associates. The obligation of all employees is to accept the proclaimed marketing plan of their school and to act in accordance with it. If only one employee acted contrary to the established internal marketing strategy, this would bring irreparable damage to the school.

However, school Principals often understand poorly the marketing (J. Kurević, 2007 ) and in most cases marketing is reduced to promotion. At the same time, the state and the competent educational authorities do nothing in terms of marketing additional training and education of Principals. The official program for training of Principals still does not exist, and the number of accredited seminars in the field of marketing in education is traditionally negligible. Thus, Principals are forced to act intuitively, randomly and experientially.

In order to percieve the current situation in our schools, data from 38 elementary school managers at the Moravian District level were collected. As a pattern and model for analysis, research conducted in Australian schools was used (Jeff Bromage, 2007) 
and the aim was to examine the opinion of the Principal as a school manager in the field of promotional activities and marketing communication of the school that he manages.

In short, some of the basic conclusions are as following:

- Promotion and marketing activities are the tasks that principals are dealing with daily

- Principals apply many marketing activities without being aware of it

- They do not know the difference between the terms of promotion and marketing, they tend to identify them, i.e. to consider promotion as marketing

- In the Annual Work Plans of their Institutions, Principals mainly provide promotional activities in the "School Marketing "section

- In a small number of cases, Principals introduce or plan to introduce a new service

- Almost everyone thinks that the most effective promotion is "talk" promotion, i.e. personal recommendation

- They do not have planned budgets for promotional activities

- They did not have any systematic training or marketing seminar

- They believe that their role in promoting school is the most important, but they expect the help of all employees

- All Principals believe that promotion and marketing are important for their school

- The most common promotional tools are the website, brochures, Open Doors Day, student performances...

However, adopting the "Rules on the Standards of Principals Competence of the Educational Institutions" in Serbia, some clarifications and order have been introduced in the areas related to the role of Principals in managing marketing activities in education. Some of them belong to typical marketing activities, such as: promoting innovations; creating a positive working atmosphere; developing professional cooperation; constructive communication with employees, pupils and parents, etc..

The school Principal (V. Logaj, 2006, p. 21) has a special task to increase the identification of teachers and pupils with school by means of his activities, to increase the reputation of the school in the local community, to create a positive image of the school and to increase the engagement of teachers in terms of satisfaction of the needs of students, parents and other users. It should also enable teachers to better meet their own needs and the requirements of the school in which they are employed. In order to realize these efforts, the Principal needs a particular plan, since it is about domains interlinking, supplementing and connecting to all areas of the Principal's work.

It is desirable for school management to adhere to certain recommendations that will enable it to efficiently model the marketing culture and effectively manage marketing in the school.

First of all, V. Filipović and M. Kostić Stanković $(2009,117)$ suggest that all school goals should be specifically established after defining the mission and directed to 4 areas:

- Efficient satisfaction of user needs

- Innovations, new content and enrichment of existing services

- Obtaining human, financial and other resources needed to provide good service

- Achieving high efficiency.

Based on these recommendations on the subject of marketing management, it follows that school management should conduct activities that directly act on the market, that it is in constant contact with the environment and should anticipate changes that 
come from the market, but the authors also recommend the opinion of M. Milisavljevic (2002), who considers marketing management as a process to initiate and direct marketing activities in order to meet needs, consisting of three phases:

- Planning - the management process stage in which decisions are made regarding the goals, policies, strategies, programs and plans of marketing activities

- Organizing - the management process stage in which the organizational structure is created and the immediate activity of the marketing function is organized

- Controlling - the stage in which the realization of planned decisions (goals, policies, strategies, programs and plans) is measured as well as the organization's efficiency, followed by corrective actions in the organization and operating of the marketing function of the organization.

American authors (J. Kouzes, B. Posner, 2012, p. 29) propose such a systematization that seems to be the most practical recommendation to Principals on how to act, or how to manage the school in order to achieve the goal of creating assumptions for developing an effective marketing culture. Within their recommendations, the authors list 5 preferred practices, behaviors, methods of work of the Principal and each proposed practice has 2 basic obligations. By realizing and implementing these practices and duties, the Principal will be positioned as a successful and exemplary manager. The Principal is primarily required to model the way that his school and employees will follow. In order to successfully model the path, he has an obligation to clarify the values that are fostered in school and to affirm common values, whereby all procedures at school need to be harmonized with those values. The Principal must inspire a common vision by anticipating the future, imagining exciting and refreshing challenges. In the process of building a common vision, he should involve other employees by referring to common intentions. During this process of building a common vision, the Principal should pose challenges by looking for opportunities to improve his work, taking the initiative, and openly seeking innovative ways to improve his work by experimenting and taking the risk to himself. It is desirable for the Principal to allow others to be active, to act, by working first on fostering cooperation, building trust and establishing close relationships. He will empower its employees by being personally an example of a commitment to improve their own professional competencies. Finally, the Principal is expected to encourage self-sacrifice, courage, sportsmanship among employees, to respect their contributions, to appreciate individual excellence and celebrate values and victories by creating a community spirit.

From the above the conclusion is that the Principal, through the realization of his role in various fields of work, and for the purpose of creating a successful school, actually creates a marketing culture that enables the attainment of that goal. By successfully applying his competencies and management method, the Principal creates the basic prerequisites for developing a marketing culture in the school. This is the reason for emphasizing the key role of Principals in this process.

\section{Conclusion}

The marketing concept can improve the operation of educational institutions and it represents the most important condition for their survival in the education market. It is also possible to accept and act upon the model of an effective marketing culture that 
would be applied in schools. By accepting such a model of effective marketing culture, the school would be able to achieve competitive advantage and better positioning in the local education market. If the school has a monopoly over the local education market, then the model of efficient marketing culture will have a priority effect on improving the quality of educational work and better meeting the needs of internal and external users.

In order to achieve a high degree of marketing culture, school management should primarily be engaged in the systematic evaluation and monitoring of the quality of work of employees and dedicated to providing full satisfaction to students, employees and parents. In such a school, all employees should strive for a common vision and plan carefully their work every day, while school management will appreciate employees who achieve top results, enable continuous professional development of teaching staff, and encourage a culture of dialogue among employees. Finally, such a school will be the first to introduce innovations into the educational process.

As this is a case with a set of interconnected and interacting elements, we can consider this marketing culture as a system, and components of marketing culture as parts of that system. This allows us to talk about the systemic approach to the theory of marketing culture in the school, since it is a unique whole of mutually dependent elements that function in harmony.

Throughout the entire reform process of developing a marketing culture in the school, the importance of the school Principal as well as of the overall school management is huge, as a function that is recognized as crucial for the quality and successful operation of a school. The Principal of the school, as a management authority in the institution, who according to the envisaged standards has the greatest responsibility for its quality and successful business, must take on new management activity in order to more completely realize the mission and vision of the institution it manages. This activity primarily relates to the establishment and development of a marketing culture. Since this is another, new tasks for the Principal, and there are more and more of them, this will definitely lead to an overload of workloads. The solution is in the redistribution of managerial tasks and the development of awareness among all employees about the necessity of developing a marketing culture in their organization, specifically in an elementary school.

From all of the above, it can be concluded that the developed marketing culture in school can be a crucial instrument for solving the most current negative phenomenon in our schools, and it refers to the phenomenon of bullying. Organizational culture characterized by intense communication among users, respect and satisfaction of their needs and expectations, is the main strategy that would preventively act on the suppression of bullying, abuse and neglect, which could be empirically checked by practical application.

\section{References}

Bajrić A., (2008). Marketinško komuniciranje šole z okolico, Master rad, Koper, Fakulteta za management

Banđur V., Potkonjak N., (2002). Istraživanje u školi, Učiteljski fakultet, Užice

Bromage J., (2008). Leadership Fellowship Report, http://studylib.net/doc/8569387/ promoting-and-marketing-your-school-effectively, ( 28.11.2015.)

Buch, T., (2003). Theories of Educational Leadership and Management, SAGE Publications, London

Dragojlović V., (2010). Modeli obuke i ispita za direktore obrazovno-vaspitnih ustanova, Centar za marketing u obrazovanju, Gornji Milanovac 
Grubor A., Đokić N., (2014). Korporativni imidž u globalnom marketingu, Anali Ekonomskog fakulteta u Subotici, Vol.50 (32), 31-38.

Kouzes J., Posner B., (2012). The Leadership Challenge - How to make extraordinary things happen in organizations, Jossey - Bass, San Francisco

Ključni podaci o obrazovanju u Evropi (2012). Izvršna agencija za obrazovanje, audiovizuelnu politiku i kulturu, EACEA Eurydice, http://eacea.ec.europa.eu/ education/eurydice/documents/key_data_series/134HR.pdf, (17.12.2016.)

Kurević J., (2007). Marketing v srednjih šolah tuzlanskega kantona, Master rad, Koper, Fakulteta za management

Logaj V., Trnavčević A., Snoj B., Biloslovo R., Kamšek M., (2006). Spreminjanje šolske kulture za povečanje identifikacije učiteljev in učenicev s šolo, Šola za ravnatelje, Ljubljana

Ljubojević Č., (2001). Menadžment i marketing usluga, Želind, Beograd

Marzano R., Waters T., McNulty B., (2005). School Leadership that works - From Research to Results, Mid-continent Research for Education and Learning, Denver

McConchie R., (1998)., Challenges for Educational Leadership in the 21st Century, www.icponline.org/disclaimer, (28.04.2013.)

Paterson K. D., Deal T. E., (1998). How leaders influence culture of schools, Educational Leadership, vol. 56., Alexandria

Pavičić J., (2001). Ishodišne determinante strateškog pristupa marketing neprofitnih organizacija: teorijska razrada, Ekonomski pregled, Zagreb, Vol. 52., 101-124.,

Pravilnik o standardima kompetencija direktora ustanova obrazovanja $i$ vaspitanja, Sl. Glasnik RS, 38/2013., Beograd

Rado P., (2002). Tranzicija u obrazovanju, Pedagoški zavod Bihać, Bihać

Republički zavod za statistiku, http://webrzs.stat.gov.rs/website/public/ReportView. aspx, (11.01.2018.)

Resman M., (1993). Management, šolstvo in šola, Sodobna pedagogika, 9-10., Ljubljana

Staničić S., (2011). Menadžment u obrazovanju, Centar za marketing u obrazovanju, Gornji Milanovac

Strategija razvoja obrazovanja u Srbiji do 20202. godine, Sl. Glasnik RS, 107/2012., Beograd

Filipović V., Kostić Stanković M., (2009). Marketing menadžment, Fakultet organizacionih nauka, Institut za menadžment, Beograd

Filipović J., Đurić M., (2010). Sistem menadžmenta kvaliteta, Fakultet organizacionih nauka, Beograd 